\title{
Abbreviations and references
}

(All places of publication: London except where noted)

AMG The Ascent of Monte Grappa (John Calder, 1991)

ASIO A Style and its Origins (Oberon Books, 2007)

AT Arguments for a Theatre (third edition, Manchester, Manchester University Press, 1997)

CP3 Collected Plays Volume Three (John Calder, 1996)

CP4 Collected Plays Volume Three (John Calder, 1998)

CP5 Collected Plays Volume Five (Calder Publications, 2001)

DH Dead Hands (Oberon, 2004)

DOAT Death, The One and The Art of Theatre (Abingdon, Routledge, 2005)

EB The Ecstatic Bible (Oberon, 2004)

FTY The Fence in its Thousandth Year (Oberon Books, 2005)

HG The Hang of the Gaol and Heaven (John Calder, 1980)

LI Lullabies for the Impatient (John Calder, 1988)

OP1 Plays One (Oberon Books, 2006)

OP2 Plays Two (Oberon Books, 2006)

OP3 Plays Three (Oberon Books, 2008)

OP4 Plays Four (Oberon Books, 2008)

OP5 Plays Five (Oberon Books, 2009)

PSD A Passion in Six Days and Downchild (John Calder, 1985)

SD Sheer Detachment (Cambridge, Salt Publishing, 2009)

SN The Swing at Night (Calder Publications, 2001)

TD The Tortmann Diaries (Calder Publications, 1996)

TGBU That Good Between Us and Credentials of a Sympathiser (John Calder, 1990)

TM Terrible Mouth (Universal Edition, 1992) 
Editions of Barker's plays, formerly published by John Calder and Calder Publications, are no longer available for order and purchase from this source (but may be available for consultation through library holdings). The plays formerly published by John Calder and Calder Publications are being republished by Oberon Books as part of their ongoing programme of making Barker's complete dramatic oeuvre available in book form. 